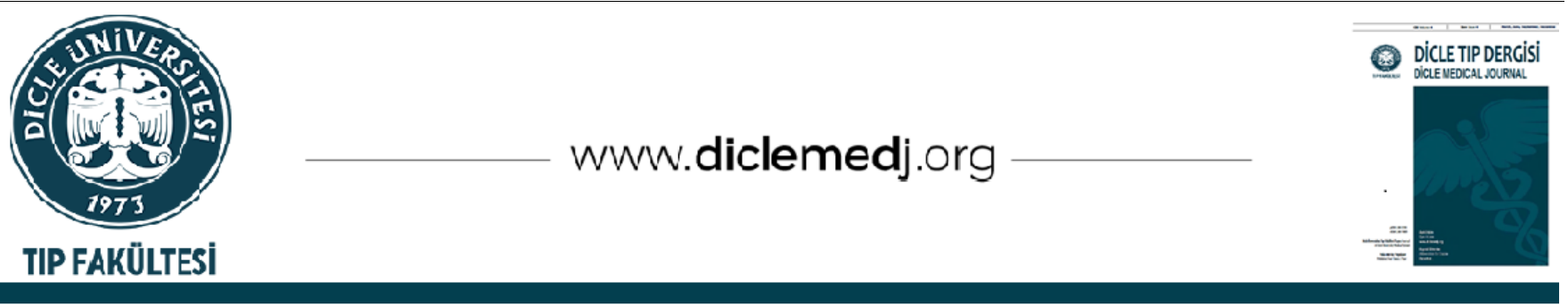

Original Article / Özgün Araştırma

\title{
COVID-19 and Other Viral Pneumonias
}

\author{
Nazlı Görmeli Kurt ${ }^{\text {iD }}{ }_{1}$, Melih Çamcı ${ }^{2}$ \\ 1 Specialist Physician, Service of Emergency Medicine, Ankara City Hospital, 06800, Ankara, Turkey \\ 2 Specialist Physician, Ağrı Training Research Hospital, Ağrı, Turkey \\ Received: 23.12.2020; Revised: 14.02.2021; Accepted: 14.02.2021
}

\begin{abstract}
Objective: Distinguishing COVID-19 pneumonia, which shares common symptoms with other respiratory viruses, from other pneumonia types will be of utmost importance for maintaining the sustainability of health services, preventing long waiting times of patients at emergency services, and isolating. We compared patients with COVID19 pneumonia and those with NONCOVID-19 pneumonia with a view to distinguishing COVID-19 pneumonia from other pneumonias.
\end{abstract}

Methods: Our study retrospectively reviewed the medical records of patients who were admitted to the emergency service of training and research hospital in Ağrı, Turkey between April 1-July 1, 2020. In our study two groups: patients with COVID-19 pneumonia and those with other pneumonias (non COVID-19) were compared in terms of demographic characteristics, laboratory data, and thoracic computerized tomography (CT) findings.

Results: Our study included 201 patients in the non COVID-19 group and 165 patients in the COVID-19 group. An analysis based on the CT findings showed that the rate of ground glass opacities (GGO) was significantly higher in the COVID-19 group ( $\mathrm{P}<0.01$ ). The rate of isolated lobar or segmental consolidation was significantly higher in the non COVID-19 group ( $\mathrm{P}<0.01$ ). The lesions had a significantly higher rate of bilateral distribution and peripheral location in the COVID-19 group ( $\mathrm{P}<0.01$ ). There was no significant difference between the two groups in terms of the mortality rate $(\mathrm{P}=0.469)$.

Conclusıon: We believe that in order to differentiate COVID-19 pneumonia from other pneumonias, a rapid thoracic computed tomography scan can be performed in the emergency department to be successfully patient management.

Keywords: COVID-19, Viral pneumonias, Emergency services.

DOI: $10.5798 /$ dicletip.887396

Correspondence / Yazışma Adresi: Nazlı Görmeli Kurt, Specialist Physician, Service of Emergency Medicine, Ankara City Hospital, 06800, Ankara, Turkey e-mail: nazligormeli@yahoo.com 


\section{COVID-19 ve Diğer Viral Pnömoniler}

Öz

Amaç: Diğer solunum yolu virüsleri ile ortak belirtiler paylaşan COVID-19 pnömonisini diğer pnömoni türlerinden ayırt etmek, sağlık hizmetlerinin sürdürülebilirliğinin sağlanması, hastaların acil servislerde uzun bekleme sürelerinin önlenmesi ve izole edilmesi açısından büyük önem taşıyacaktır. COVID-19 pnömonisini diğer pnömonilerden ayırt etmek amacıyla COVID-19 pnömonisi ve NONCOVID-19 pnömonisi olan hastaları karşılaştırdık.

Yöntemler: Çalışmamızda 1 Nisan-1 Temmuz 2020 tarihleri arasında Ağrı Eğitim ve Araştırma Hastanesinin acil servisine başvuran hastaların tıbbi kayıtları geriye dönük olarak gözden geçirilmiştir. Çalışmamızda iki grup: COVID-19 pnömonili hastalar ve diğer pnömoniler (COVID-19 olmayan), demografik özellikler, laboratuvar verileri ve bilgisayarlı torasik tomografi (BT) bulguları açısından karşılaştırıldı.

Bulgular: Çalışmamıza COVID-19 dişı grupta 201 hasta ve COVID-19 grubunda 165 hasta dahil edildi. BT bulgularına dayanan bir analiz, buzlu cam opasitelerinin (GGO) oranının COVID-19 grubunda önemli ölçüde daha yüksek olduğunu gösterdi $(\mathrm{P}<0.01)$. İzole lober veya segmental konsolidasyon oranı COVID-19 olmayan grupta anlamlı olarak daha yüksekti ( $\mathrm{P}<0.01)$. COVID-19 grubunda lezyonlar anlamlı olarak daha yüksek oranda bilateral dağılım ve periferik yerleşime sahipti $(\mathrm{P}<0.01)$. Ölüm oranı açısından iki grup arasında anlamlı bir fark yoktu $(\mathrm{P}=0.469)$.

Sonuç: COVID-19 pnömonisini diğer pnömonilerden ayırt etmek için acil serviste hızlı toraks bilgisayarlı tomografi taraması yapılabileceğine ve başarılı bir şekilde hasta yönetimi sağlanabileceğine inanıyoruz.

Anahtar kelimeler: COVID-19, Viral pnömoniler, Acil servisler.

\section{INTRODUCTION}

At the end of 2019, a novel coronavirus was defined as the cause of a group of pneumonia cases in Wuhan, a city in the Hubei province of China. Afterwards, the virus has rapidly spread first in China and then all over the world and became a global public health problem ${ }^{1}$. The World Health Organization (WHO) designated the disease as the novel coronavirus disease (COVID-19) in February 2020 and declared it a pandemic on March 11, 20202,3. Coronaviruses are important human and animal pathogens. SARS-CoV, SARS-CoV-2, MERSCoV, HcoV-NL63, HcoV-HKU1, and HcoV-OC43 are the six serotypes that cause infection in humans ${ }^{4}$ while cold coronaviruses also cause seasonal infections. In an eight year study that was conducted in the United States, it was reported that cold coronaviruses were detected in December and May, with the main disease peaks occurring in January and February. The same study also noted that cold coronaviruses were detected in only $2.5 \%$ of common cold cases in the period between June and September 5 . The first case in Turkey was diagnosed on March 10, 2020; with the announcement of the pandemic by the World Health Organization immediately thereafter, various measures have been taken to prevent the spread of the virus in our country ${ }^{6}$. Thanks to the announcement of the early start of summer vacation for schools and transition to online education system, curfew imposed on individuals under the age of 20 and over the age of 65 , restrictions imposed on places such as mass entertainment venues, theaters as well as public transport, and "Wear a Mask, Keep Your Distance, Stay Home" calls made by the government, virus spread could be controlled for June-July-August ${ }^{7}$. September and beyond will be months when the number of cases will soar due to lifting of restrictions and re-opening of schools; furthermore, these are the months in which cold coronavirus cases peak. It is extremely important to distinguish COVID-19 pneumonia from other viral pneumonias, especially in these periods when all respiratory diseases are on the rise. Although reverse transcription-polymerase chain reaction is the gold standard test for the diagnosis of COVID-19, the test's high false negativity rate, the requirement of repeat tests for definitive exclusion, and delayed test results cause delays in isolation and treatment ${ }^{8}$. During this period, when the number of respiratory diseases increases, distinguishing COVID-19 pneumonia from other pneumonias at the time of admission will be extremely important in terms of the sustainability of healthcare systems and 
prevention of long waiting times for patients at emergency services.

\section{OBJECTIVE}

We aimed to compare the demographic characteristics, laboratory data, and thoracic computerized tomography findings of patients with COVID-19 pneumonia and patients with other pneumonia types (non-COVID-19) who presented to the study hospital during the COVID-19 pandemic.

\section{METHOD}

This research was started after approval had been obtained from the clinical research ethics committee of the training and research hospital (date: October 7, 2020; number: 10). Our study retrospectively reviewed the medical records of patients who presented to the emergency service of a training and research hospital in Ağrı, Turkey, between April 1, 2020, and July 1, 2020, and whose thoracic computerized tomography examination showed signs of pneumonia. The patients were divided into two groups based on reverse transcriptionpolymerase chain reaction results, as the patients with COVID-19 pneumonia and those with other pneumonias (non-COVID-19). Two reverse transcription-polymerase chain reaction tests were performed two days apart in all patients, and patients with three negative tests sent within one week were included in the non-COVID-19 group. Patients under the age of 18 and those with missing medical records in the hospital automation system were excluded. The two groups were compared in terms of demographic characteristics, admission complaints, laboratory parameters, and radiological findings.

\section{Statistical Analysis}

IBM SPSS Statistics for Windows, Version 22.0 (IBM Corp., Armonk, United States of America) software package was used for data analysis. Normality of distribution of the study data was tested using Kolmogorov-Smirnov test. The descriptive statistics included mean \pm standard deviation for normally distributed variables and median (minimummaximum) for non-normally distributed study variables. Mann Whitney-U test was used to compare non-normally quantitative variables while independent samples T-test was used for normally distributed quantitative variables. Statistical significance was set at $\mathrm{P}<0.05$.

\section{RESULTS}

A total of 27,816 patients were admitted to the emergency service the study hospital between April 1,2020 , and July 1, 2020. Of these, 378 patients were found to have pneumonia on thoracic computerized tomography and admitted to the hospital. Twelve patients whose data were inaccessible at Hospital Automation System were excluded. Among the remaining 366 patients, 201 patients tested negative in all 3 repeat reverse transcriptionpolymerase chain reaction tests performed within a week, and were included in the non-COVID-19 group. One hundred and sixty-five patients with positive reverse transcription-polymerase chain reaction test formed the COVID-19 group. Due to a limited number of inpatient services in the hospital, patients who had a stable clinical course and no comorbidity were discharged with prescription medicines and instructed to stay isolated at home. Thus, all patients who were hospitalized and included in our study had at least one comorbidity. The mean age of the non-COVID group was $48.6 \pm$ 21.7 years while the mean age of the COVID-19 group was $42.9 \pm 19.6$ years $(\mathrm{P}=0.324)$. In the nonCOVID-19 group, 201 (58.7\%) patients were male while 102 (61.8\%) patients in the COVID-19 group were male $(\mathrm{P}=0.251)$. The two groups did not significantly differ in terms of mean age and sex (Table 1). Among 366 patients, only 39 (10.6\%) were free of any history of suspected COVID-19 contact. One hundred and seventy-three (86\%) patients in the non-COVID-19 group and 154 (93\%) patients in the COVID-19 group had a history of suspected COVID-19 contact $(\mathrm{P}=0.126)$. The most common admission symptoms in both groups were fever and cough; however, dyspnea $(\mathrm{P}=0.03)$ and arthralgia $(\mathrm{P}=0.001)$ were more common in the COVID-19 group when compared to the non-COVID19 group. Seven (3.4\%) patients in the non-COVID19 group and 4 (2.4\%) patients in the COVID-19 group died. The two groups did not differ significantly with regard to the mortality rate $(\mathrm{P}=$ 0.127) (Table 1). 
Table I: Clinical and demographic characteristics of COVID-19 and non-COVID-19 patients

\begin{tabular}{|c|c|c|c|}
\hline & $\begin{array}{l}\text { Non-COVID- } \\
19 \\
(n=201)\end{array}$ & $\begin{array}{l}\text { COVID-19 } \\
(n=165)\end{array}$ & $P$ value \\
\hline $\begin{array}{l}\text { Mean age } \\
(\text { mean } \pm S D)\end{array}$ & $48.6 \pm 21.7$ & $42.9 \pm 19.6$ & 0.324 \\
\hline Male sex n (\%) & $201(58.7 \%)$ & $102(61.8 \%)$ & 0.251 \\
\hline $\begin{array}{l}\text { History of suspected } \\
\text { contact n (\%) }\end{array}$ & $173(86 \%)$ & $154(93 \%)$ & 0.126 \\
\hline $\begin{array}{l}\text { Admission complaint } \\
\text { n (\%) }\end{array}$ & & & \\
\hline Fever & $164(82 \%)$ & $149(91 \%)$ & 0.541 \\
\hline Cough & $108(53.7 \%)$ & $112(68 \%)$ & 0.425 \\
\hline Dyspnea & $22(10 \%)$ & $59(35 \%)$ & 0.03 \\
\hline Sore throat & $14(7 \%)$ & $9(5.4 \%)$ & 0.431 \\
\hline Diarrhea & $6(3 \%)$ & $11(6 \%)$ & 0.476 \\
\hline Weakness & $84(42 \%)$ & $62(37.5 \%)$ & 0.372 \\
\hline Arthralgia & $46(22 \%)$ & $98(59.3 \%)$ & 0.001 \\
\hline Length of hospital stay & $12 \pm 10$ & $13 \pm 9$ & 0.53 \\
\hline Mortality n (\%) & $7(3.4 \%)$ & $4(2.4 \%)$ & 0.127 \\
\hline
\end{tabular}

An analysis of the patients in terms of thoracic computerized tomography findings revealed that 151 (91.5\%) patients in the COVID-19 group had the ground glass opacity (GGO) sign, with its most common pattern being the "pureground glass opacity", which had a rate of $63.5 \%$, followed by ground glass opacity + fine reticulation with a rate of $16.5 \%$. On the other hand, only 12 (5.9\%) patients in the non-COVID-19 group had ground glass opacity. We found a significantly higher rate of ground glass opacity in the COVID-19 group $(\mathrm{P}<0.01)$.

In the non-COVID-19 group, $172(85.5 \%)$ patients had signs of isolated lobar or segmental consolidation, which was statistically significant (P
< 0.01). The lesions were bilateral in 118 (71.5\%) patients in the COVID-19 group and $44(21.8 \%)$ in the non-COVID-19 group. Bilateral lesion distribution was significantly more common in the COVID-19 group $(\mathrm{P}<0.01)$. One hundred and twenty-seven (76.9\%) patients in the COVID-19 group and 72 (36\%) patients in the non-COVID-19 had peripherally located pulmonary lesions; the rate of peripheral lesion location in the COVID-19 group was significantly higher $(\mathrm{P}<0.01)$ (Table 2$)$.

Table II: Findings on thoracic computerized tomography in patients with COVID-19 and non-COVID-19

\begin{tabular}{|c|c|c|c|}
\hline & $\begin{array}{l}\text { Non-COVID- } \\
19 \\
(n=201)\end{array}$ & $\begin{array}{l}\text { COVID-19 } \\
(n=165)\end{array}$ & $\begin{array}{l}P \\
\text { value }\end{array}$ \\
\hline \multicolumn{4}{|l|}{ Characteristics n(\%) } \\
\hline $\begin{array}{l}\text { Isolated lobar or segmental } \\
\text { consolidation }\end{array}$ & $172(85.5 \%)$ & $7(4.2 \%)$ & $<0.01$ \\
\hline GGO* & $12(5.9 \%)$ & $151(91.5 \%)$ & $<0.01$ \\
\hline Pure GGO & $3(25 \%)$ & $96(63.5 \%)$ & \\
\hline GGO + Fine reticulation & $2(16.6 \%)$ & $25(16.5 \%)$ & \\
\hline GGO + Air bronchogram & $2(16.6 \%)$ & $17(11.2 \%)$ & \\
\hline GGO + Consolidation & $5(41.6 \%)$ & $13(8.6 \%)$ & \\
\hline \multicolumn{4}{|l|}{ Distribution n(\%) } \\
\hline Bilateral & $44(21.8 \%)$ & $118(71.5 \%)$ & $<0.01$ \\
\hline Unilateral & $157(78.2 \%)$ & 47 (28.5\%) & $<0.01$ \\
\hline Right & $89(56.6 \%)$ & $29(61.7 \%)$ & \\
\hline Left & $68(44.4 \%)$ & $18(38.3 \%)$ & \\
\hline \multicolumn{4}{|l|}{$\begin{array}{l}\text { Transverse distribution } \mathbf{n} \\
(\%)\end{array}$} \\
\hline Central & $129(64 \%)$ & $38(23.1 \%)$ & $<0.01$ \\
\hline Peripheral & $72(36 \%)$ & $127(76.9 \%)$ & $<0.01$ \\
\hline
\end{tabular}


A comparison of the patients in the COVID-19 and non-COVID-19 groups in terms of admission laboratory parameters revealed no significant difference between the two groups with respect to laboratory parameters, except for lymphopenia $(\mathrm{P}=0.01)$ (Table 3).

Table III: Laboratory data of theCOVID-19 and nonCOVID-19 patients

\begin{tabular}{|c|c|c|c|}
\hline & $\begin{array}{l}\text { Non-COVID-19 } \\
(\mathrm{n}=201)\end{array}$ & $\begin{array}{l}\text { COVID-19 } \\
(\mathrm{n}=165)\end{array}$ & $\begin{array}{l}P \\
\text { value }\end{array}$ \\
\hline $\begin{array}{l}\text { White blood cell count, } \\
\times 10^{9} / \mathrm{L}\end{array}$ & $7.4(4.7-8.8)$ & $6.7(4.0-7.9)$ & 0.38 \\
\hline Neutrophil count, $\times 10^{9} / \mathrm{L}$ & $6.6(2.1-8.1)$ & $5.8(2.4-6.8)$ & 0.46 \\
\hline $\begin{array}{l}\text { Lymphocyte count, } \\
\times 10^{9} / \mathrm{L}\end{array}$ & $0.9(0.6-1.1)$ & $0.4(0.2-0.8)$ & 0.01 \\
\hline Platelet count, $\times 10^{9} / \mathrm{L}$ & $141(134-233)$ & $158(142-251)$ & 0.74 \\
\hline Prothrombin time, s & $11.3(8.2-13.1)$ & $12.4(9.8-14.2)$ & 0.34 \\
\hline $\begin{array}{l}\text { Activated partial } \\
\text { thromboplastin time, } s\end{array}$ & $25.3(22.5-36.7)$ & $26.9(22.4-35.1)$ & 0.86 \\
\hline D-dimer, mg/L & $0.8(0.3-1.1)$ & $1.0(0.3-1.4)$ & 0.08 \\
\hline $\begin{array}{l}\text { Lactate dehydrogenase, } \\
\text { U/L }\end{array}$ & $314(256-71)$ & $358(295-461)$ & 0.56 \\
\hline Albumin, g/L & $31.2(28.4-39.5)$ & $29.7(26.3-37.2)$ & 0.16 \\
\hline $\begin{array}{l}\text { Alanine } \\
\text { aminotransferase, } \mathrm{U} / \mathrm{L}\end{array}$ & $34.7(26.3-48.9)$ & $37.5(28.5-51.4)$ & 0.46 \\
\hline $\begin{array}{l}\text { Aspartate } \\
\text { aminotransferase, U/L }\end{array}$ & $29(25.6-41.7)$ & $36.2(23.8-55.3)$ & 0.33 \\
\hline Total bilirubin, mmol/L & $10.7(9.2-4.1)$ & $12.5(10.2-16.6)$ & 0.07 \\
\hline
\end{tabular}

\section{DISCUSSION}

Following the report of the first case of COVID19 on December 1, 2019, the virus has spread globally and infected about 26.7 million people worldwide to this date 9 . In our country, the number of cases decreased in March, April, and May 2020 by paying attention to social distance rule, making calls to stay at home, switching to online education system in schools, and the closure of social areas such as cinemas, theaters ${ }^{7}$. However, as of June 1, travel restrictions and curfew have been lifted, and in July, cinemas, theaters and wedding halls have been reopened. No restrictions were imposed on the Feast of Sacrifice which was celebrated between 31 July and 3 August, when people traditionally make collective family visits. Lifting the restrictions has been reflected in the number of cases since August ${ }^{10}$. hospital visits have increased, and the already crowded emergency services have become even more crowded. Furthermore, people avoided visiting hospitals due to the fear of getting the infection during the restrictions, which particularly interrupted follow-up of patients with chronic disorders. This, in turn, has led to an increased frequency of hospital admissions of chronic disorders with even worse prognosis ${ }^{10}$. A higher occupation rate has been reached for inpatient services and intensive care units due to increasing number of cases. There is another serious problem apart from overcrowding of emergency services, which are the places where first admission and evaluation of patients are carried out: a rapid differentiation between COVID-19 and non-COVID-19 must be done. Moreover, starting from September, respiratory diseases due to influenza and other respiratory viruses will increase, and it will be extremely important for emergency services to rapidly distinguish COVID-19 pneumonia, which has common symptoms with other respiratory viruses, at the time of admission. Therefore, in our study, we compared patients with COVID19 pneumonia and non-COVID-19 pneumonia in order to distinguish COVID-19 pneumonia from other pneumonias at the time of emergency service admission. We found that the demographic characteristics such as age and sex did not create any significant difference between the study groups. The rate of suspected contacts was also high for the people of Ağrı who frequently gathered in crowds for traditional activities such as weddings, funerals 
and sacrifices when the restrictions were lifted, but this situation did not make a significant difference between the two groups. All patients in our study were hospitalized due to having an additional comorbidity; although mortality rate and length of hospital stay have a wide spectrum in COVID-19 patients, we did not find any significant difference between COVID-19 pneumonia and other pneumonias in this regard ${ }^{11}$. While the most common admission complaints were fever and cough in both groups, arthralgia and dyspnea were more common in COVID-19 pneumonia ${ }^{12}$. Similar to other studies, among other blood parameters, only lymphopenia were found significantly higher in the COVID-19 group 13,14 . An analysis of thoracic computerized tomography findings revealed that the COVID-19 group had the typical sign of bilateral, peripherally located ground glass opacity (GGO) ${ }^{15-18}$. Although reverse transcription-polymerase chain reaction-test is the gold standard for the diagnosis, its collection and study time are not standardized across hospitals. In Turkey, overcrowded emergency services make working conditions very hard for healthcare workers. 7 Waiting times as long as 12-16 hours in our hospital interrupt the emergency services. A failure to admit patients to inpatient services and intensive care units separated as COVID-19 and non-COVID-19 services, as well as a failure to isolate these patients in the emergency service before test results become available increase the risk of communicating the disease both by patients and healthcare staff and prolong the time to start appropriate therapy. Thus, we are of the opinion that the management plans of pneumonia cases, which we predict to increase in fall and winter months, should be based on the findings on thoracic computerized tomography that can be rapidly performed in emergency services. In this way, patients can be isolated without having to wait for the reverse transcription-polymerase chain reaction results for as long as 12-16 hours, emergency services' viral load will be reduced by early isolation, fewer healthcare workers will be infected, and the patients will start to be treated as early as possible. There are some limitations; a higher number of cases and a multi-center study will contribute to this issue.

\section{CONCLUSION}

It will be of critical importance for the sustainability of healthcare services to distinguish COVID-19 pneumonia from other pneumonias, which share common symptoms, in fall and winter seasons when the frequency of respiratory diseases increases. In addition to a low specificity of the reverse transcriptionpolymerase chain reaction test performed to diagnose the disease, the time to obtain the results varies among hospitals depending on collection type and laboratory process, and the completion of the test may take up to 12-16 hours. We believe that patient management should be based on the findings of thoracic computerized tomography, which is rapidly performed at emergency services. In this way, patients will have an opportunity to receive a rapid diagnosis, treatment, and isolation while the crowd of emergency services will be reduced and healthcare workers will not be exposed to unnecessarily excessive viral load, and thus have a lessened risk of getting the infection.

Ethical Committee Approval: This research was started after approval had been obtained from the clinical research ethics committee of the training and research hospital (date: October 7, 2020; number: 10).

Declaration of Conflicting Interests: The authors declare that they have no conflict of interest.

Financial Disclosure: No financial support was received. 


\section{REFERENCES}

1. World Health Organization. Director-General's remarks at the media briefing on 2019-nCoV on 11 February 2020. Available from: http://www.who.int/dg/speeches/detail/whodirector-general-s-remarks-at-the-media-briefingon-2019-ncov-on-11-february-2020. (Accessed in 2020 (Oct 19).

2. Park SE. Epidemiology, virology, and clinical features of severe acute respiratory syndrome coronavirus-2 (SARS-CoV-2; Coronavirus Disease19). Clin Exp Pediatr. 2020; 63: 119-24.PMID: 32252141; doi: 10.3345/cep.2020.00493.

3. Lai CC, Wang CY, Wang YH, et al. Global epidemiology of coronavirus disease 2019 (COVID19): disease incidence, daily cumulative index, mortality, and their association with country healthcare resources and economic status. Int J Antimicrob Agents. 2020; 55: 105946. PMID: 32199877; doi:10.1016/j.ijantimicag.2020.105946.

4. Anthony SJ, Johnson CK, Greig DJ, et al. Global patterns in coronavirus diversity. Virus Evol. 2017; 3: vex012. PMID: 28630747; doi: $10.1093 / v e / v e x 012$.

5. Monto AS, DeJonge PM, Callear AP, et al. Coronavirus Occurrence and Transmission Over 8 Years in the HIVE Cohort of Households in Michigan. J Infect Dis. 2020; 222: 9-16. PMID: 32246136; doi: 10.1093/infdis/jiaa161.

6. Demirbilek Y, Pehlivantürk G, Özgüler ZÖ, Alp Meșe E. COVID-19 outbreak control, example of ministry of health of Turkey. Turk J Med Sci. (2020;50 (SI-1): 489-94. PMID: 32304192; doi: 10.3906/sag-2004-187.

7. Gormeli Kurt N, Gunes C. How has Covid-19 pandemic affected crowded emergency services? Int J Clin Pract. 2020;00:e13624.5. doi: 10.1111/ijcp.13624.

8. Ai T, Yang Z, Hou H, et al. Correlation of Chest CT and RT-PCR Testing for Coronavirus Disease 2019 (COVID-19) in China: A Report of 1014 Cases. Radiology. 2020; 296: E32-40. PMID: 32101510; doi: 10.1148/radiol.2020200642.

9. World Health Organization. WHO Coronavirus Disease (COVID-19) Dashboard. Available from: https://covid19.who.int/ Accessed in 2020 (Oct 19).
10. Available from:

https://covid19.saglik.gov.tr/TR-66122/genelkoronavirus-tablosu.html. T.C. Sağlık Bakanlığı.

11. World Health Organization. Report of the WHOChina Joint Mission on Coronavirus DIsease 2019 (COVID-2019). 16-24 February, 2020. Available from: http://www.who.int/docs/defaultsource/coronaviruse/who-china-joint-mission-oncovid-19-final-report.pdf. (Accessed, in 2020 (Oct 19).

12. Stokes EK, Zambrano LD, Anderson KN, et al. Coronavirus Disease 2019 Case Surveillance United States, January 22-May 30, 2020. MMWR Morb Mortal Wkly Rep. 2020; 69: 759-65. PMID: 32555134; doi: 10.15585/mmwr.mm6924e2.

13. Huang C, Wang Y, Li X, et al. Clinical features of patients infected with 2019 novel coronavirus in Wuhan, China. Lancet. 2020; 395(10223): 497-506. PMID: 31986264; doi: 10.1016/S01406736(20)30183-5.

14. Wang D, Hu B, Hu C, et al. Clinical Characteristics of 138 Hospitalized Patients With 2019 Novel Coronavirus-Infected Pneumonia in Wuhan, China. JAMA. 2020;323: 1061-9. PMID: 32031570; doi: 10.1001/jama.2020.1585.

15. Bao C, Liu X, Zhang H, et al. Coronavirus Disease 2019 (COVID-19) CT Findings: A Systematic Review and Meta-analysis. J Am Coll Radiol. 2020; 17: 7019. PMID: 32283052; doi: 10.1016/j.jacr.2020.03.006.

16. Zhao W, Zhong Z, Xie X,Yu Q, Liu. Relation Between Chest CT Findings and Clinical Conditions of Coronavirus Disease (COVID-19) Pneumonia: A Multicenter Study. AJR Am J Roentgenol. 2020; 214: 1072-7. PMID: 32125873; doi: 10.2214/AJR.20.22976.

17. Acute Kidney Injury Associated with SARS-CoV2. Şit D., Kayabaşı H.,Cilt 47, Sayı 2 (2020) 498-507 doi:10.5798/dicletip.755786

18. Shi H, Han X, Jiang N, et al. Radiological findings from 81 patients with COVID-19 pneumonia in Wuhan, China: a descriptive study. Lancet Infect Dis. 2020; 20: 425-34. PMID: 32105637; doi: 10.1016/S1473-3099(20)30086-4. 